\title{
U.S. Grass-Fed Beef Producers: Goal Structure and Reasons for Enterprise Selection
}

\author{
Isaac Sitienei ${ }^{1 \star \star}\left(\mathbb{D}\right.$, Jeffrey Gillespie ${ }^{2}$ and Guillermo Scaglia ${ }^{3}$ \\ ${ }^{1}$ Department of Agriculture, Austin Peay State University, Clarksville, Tennessee, USA, ${ }^{2}$ U.S. Department of Agriculture, \\ Economic Research Service, Washington, DC, USA and ${ }^{3}$ Iberia Research Station, Louisiana State University Agricultural \\ Center, Jeanerette, Louisiana, USA \\ ${ }^{\star}$ Corresponding author. Email: sitieneii@apsu.edu
}

\begin{abstract}
We examine the relative importance of eight goals U.S. grass-fed beef (GFB) producers have for their farms and the relative importance of nine reasons for selecting the GFB enterprise. We further analyze factors affecting goal structure and reasons for selecting the enterprise. The data used for this study are from a 2013 mail survey of U.S. GFB producers. The most important reasons for selecting the GFB enterprise included "producing healthy beef" and "GFB is good for the environment," classified in the study as social and environmental sustainability reasons, respectively. Reasons such as "profitability" and "strong demand for GFB" were generally of lower importance.
\end{abstract}

Keywords: Fuzzy pairwise comparisons; goal structure; grass-fed beef; reasons for farming

JEL Classifications: Q12; Q16

\section{Introduction}

During recent years, U.S. consumer demand for beef raised under alternative production systems has risen (Mathews and Johnson, 2013), with producers responding by expanding production under these systems. One of the alternative production systems that has gained interest in the United States has been the grass-fed beef (GFB) system. Some of the reasons for increased interest in GFB relate to consumer perceptions of health and environmental benefits associated with beef raised exclusively on pasture and forage, without grain. Concerns over antibiotic use, animal welfare, and the use of growth promotants have also boosted GFB demand (Lusk, Roosen, and Fox, 2003; Spiselman, 2006). Though we do not have a firm estimate of the current extent of the GFB market, it appears to be growing. Gwin (2009) estimated that the GFB herd accounted for $<0.5 \%$ of the total beef herd in 2009. Mathews and Johnson (2013) suggested that in 2013, alternative production systems (organic, GFB, and natural) likely accounted for more than $3 \%$ of the beef marketed, with an expected annual growth rate of $20 \%$, effectively doubling the market share after 5 years. Observations of grocery store and restaurant GFB offerings in recent years suggest greater availability of the product.

Though research has examined consumer preferences for GFB relative to conventional beef (Gwin et al., 2012; McCluskey et al., 2005) and consumer willingness to pay for GFB (Umberger et al., 2002; Xue et al., 2010), limited work has addressed motivations of producers to produce GFB (Lozier, Rayburn, and Shaw, 2006; Steinberg and Comerford, 2009). In order to consider the future potential of GFB production, a better understanding is needed of the reasons producers elect to produce GFB and their goals associated with farming.

(C) The Author(s) 2019. This is an Open Access article, distributed under the terms of the Creative Commons Attribution licence (https:// creativecommons.org/licenses/by/4.0/), which permits unrestricted re-use, distribution, and reproduction in any medium, provided the original work is properly cited. 
To understand why GFB producers might have different motivations for farming than other farmers, knowledge of the unique characteristics of a GFB production system is needed. The U.S. Department of Agriculture (USDA) defined a number of GFB production standards in 2006 that are not required of conventional beef production. In GFB systems, grain and grain byproducts cannot be fed, and the animal must have access to pasture during the forage growing season. From weaning until slaughter, the animal's diet must consist only of forage: forbs, browse, cereal grain crops in their vegetative state, and grass, while before weaning, milk from the dam (mother) is also accepted. Hay, crop residue without grain, silage, baleage, haylage, and other roughage are permitted, and vitamin and mineral supplementation are allowed (U.S. Department of Agriculture, Agricultural Marketing Service [USDA-AMS], 2018). The USDA rescinded the grass-fed marketing claim in 2016 as discussed by USDA-AMS (2016), but the American Grassfed Association continues to certify producers. Their standards address origin, antibiotics, hormones, diet, and confinement (American Grassfed Association, 2018). In contrast, typical conventional beef production involves feeding weaned or backgrounded animals to slaughter weight in a feedlot on a ration that includes grain.

There are a number of reasons why GFB producers might have different goals and reasons for selecting the beef enterprise than conventional beef producers. GFB producers are involved in the beef finishing stage, with much of the end product of the farm being sold as beef (rather than an animal). Gillespie et al. (2016b) show that $96 \%$ of GFB producers sell beef direct to consumers, $39 \%$ sell online, $36 \%$ sell via farmers' markets, $31 \%$ sell directly to restaurants, and $18 \%$ sell directly to grocery stores (producers could have chosen more than one marketing outlet; thus percentages do not sum to 100). Hence, beef quality can be expected to be linked directly with the producer, rather than the more typical case in conventional beef production where an animal is produced on the farm and sold to a downstream source, with the packer more likely linked with beef quality. Considering the requirements for GFB production and the often closer relationship between producers and consumers of beef, it is conceivable that producer motivations for farming and goals for the farm would differ from those of conventional producers.

GFB producers may have entered into GFB production for reasons other than traditional economic reasons such as profit maximization or cost minimization. Lozier, Rayburn, and Shaw (2006) discuss the complexity of the decision to enter into a GFB enterprise relative to a conventional beef enterprise, acknowledging that the decision cannot be reduced to a "prescriptive formula." Results of a survey of 26 northeastern U.S. GFB producers by Steinberg and Comerford (2009) suggest that the top 4 of 10 reasons GFB producers produce GFB are, from the most to the least important, human health issues, animal welfare concerns and environmental concerns (tie), and lifestyle. "Profit" and "available markets" were tied for fifth place. As we have interacted with U.S. GFB producers over a number of years through research and extension programs, a variety of motivations for entering into GFB production have been discussed, including but not limited to the desire to produce food under a sustainable production system, to produce a healthy food product, and to be able to interact directly with consumers. Limited work has examined the profitability associated with GFB production; Qushim et al. (2018) found profitability of U.S. GFB farms to vary dependent on farm size.

Most studies conducted in agricultural economics have focused on profit maximization and/or cost minimization as the important considerations for a farming enterprise. Although these must be considerations for most producers, they are not the only goals producers consider in decision making (Kliebenstein et al., 1980). Producer goals are generally multidimensional rather than unidimensional (Patrick, Blake, and Whitaker, 1983; Smith and Capstick, 1976). Though significant literature has examined farmers' goals (Kliebenstein et al., 1980; Patrick, Blake, and Whitaker, 1983; Smith and Capstick, 1976; van Kooten, Schoney, and Hayward, 1986), relatively few studies have examined how goals differ by production enterprise (Basarir and Gillespie, 2006), how goal structure affects other decisions such as farm size (Bergevoet et al., 2004), how different reasons 
for entering farming affect enterprise selection (Gillespie and Mishra, 2011), or goal structure of farmers producing under alternative production systems (Peterson et al., 2012).

The objectives of this study are to determine (1) the reasons U.S. farmers selected the GFB enterprise for their farms, (2) the relative importance of potential goals U.S. GFB producers have for their farms, and (3) the factors that affect producers' reasons for selecting the GFB enterprise and the relative importance of various goals for GFB producers. Better understanding of the motivations of GFB producers will assist university personnel and consultants with an interest in working in the area of GFB production, providing context for developing extension and research programs that can more fully address GFB producer concerns.

A mail survey of U.S. GFB producers was conducted for this study. Five-point Likert scale questions were used to elicit the importance of nine potential reasons why producers entered into GFB production. Ordered probit models were used to determine the factors that influence these reasons. Fuzzy pairwise comparisons were used to determine the relative importance of eight potential goals GFB producers have for their operations, and ordinary least squares (OLS) regression analysis was used to determine factors that influence goal importance.

\section{Data and methods}

The data used in this study are from a 2013 mail survey of U.S. GFB producers. An extensive Internet search was conducted in 2013 to develop a list of 1,052 names and addresses of U.S. GFB producers for survey. Among the Internet sources used were eatwild.com, Market Maker, and the American Grassfed Association. Searches were also conducted for GFB producers who managed their own websites using search terms such as "grass-fed," "grass-finished," forage-fed," and so forth. All GFB producers for which an address was found were surveyed.

A survey package containing a personally addressed and signed cover letter, a 10-page questionnaire, and a postage-paid return envelope was mailed to all 1,052 addresses. This was followed 2 weeks later by a postcard reminder. A second signed letter, questionnaire, and postage-paid return envelope were mailed 2 weeks after the postcard to all nonrespondents. This was followed 2 weeks later with a second postcard reminder. All mail was sent first class so that incorrect addresses would be returned to us. The study by Dillman, Smyth, and Christian (2009) was used as a guide in developing and conducting the survey. A total of 384 usable responses were received. Deducting return-to-sender addresses and respondents who indicated that they had not produced GFB in 2012, this was an adjusted return rate of $41 \%$.

A definition of GFB was provided at the beginning of the questionnaire to ensure that responses from only GFB producers were obtained. The U.S. Census of Agriculture has not published numbers of GFB farms, so it is difficult to determine the representativeness of our sample. Several indicators, however, provide information. The American Grassfed Association included 187 GFB farms at the time of our survey, and those producers were sent surveys. The USDA-AMS has a Grass Fed Small and Very Small (SVS) Producer Program that included 56 GFB farms on March 4, 2019; there was some overlap with the American Grassfed Association list. Our 384 respondents were from all 50 U.S. states except for Alaska, Delaware, Hawaii, North Dakota, and Vermont. Of the combined American Grassfed Association and USDA-AMS SVS producers, only three producers were located in one of the five states not represented in our sample. Furthermore, given the nature of GFB production-a differentiated product often sold via multiple outlets (direct marketing to consumers, restaurants, and grocery stores) - it is expected that a relatively high percentage of GFB producers advertise via the Internet and thus would have been surveyed.

Comparing our sample with U.S. cattle producers who responded to USDA's 2008 Agricultural Resource Management Survey (ARMS) cow-calf survey (McBride and Mathews, 2011), weighted to represent the U.S. cow-calf producer population, our producers operated an average of 1,538 
acres (median $=233$ acres) compared with 1,316, 1,623, and 1,407 acres for all U.S. cow-calf, cowcalf with stocker, and cow-calf with feedlot operations, respectively. Our average operator age was 55 years compared with 60, 59, and 56 years for all U.S. cow-calf, cow-calf with stocker, and cowcalf with feedlot operations, respectively. Sixty percent of our producers held off-farm jobs, compared with $36 \%, 34 \%$, and $20 \%$ for all U.S. cow-calf, cow-calf with stocker, and cow-calf with feedlot operations, respectively. Seventy percent of our producers had completed college degrees compared with $26 \%, 29 \%$, and $27 \%$ of all U.S. cow-calf, cow-calf with stocker, and cow-calf with feedlot operations, respectively. Thus, compared with U.S. cow-calf operations, higher percentages of our producers held off-farm jobs and had obtained college degrees. Whether the discrepancies represent differences in producer populations by segment or a tendency for more highly educated producers with off-farm jobs to respond to our survey cannot be determined without further surveying that is weighted to the U.S. producer population.

Besides goal structure and reasons for selecting the GFB enterprise questions, other survey questions dealt with cattle breed used, application of technologies, preferences for animal characteristics for finishing, description of the forage system used, challenges faced in producing $\mathrm{GFB}$, marketing of GFB, and general farm structure and producer demographics.

\subsection{Eliciting producer reasons for selecting the grass-fed beef enterprise}

Respondents were asked to indicate their reasons for selecting the GFB enterprise using Likertscale questions. Potential reasons were selected for the survey on the basis of economic theoretic reasons, the authors' knowledge of GFB systems, discussion with GFB producers prior to the survey, and previous literature (Steinberg and Comerford, 2009). Each of these reasons falls into one or more of four classifications we developed. These classifications include the three domains of sustainability, including economic, social, and environmental sustainability, plus an additional classification for lifestyle. Goodland (1995, p. 3, figure 1) states that economic sustainability is generally accepted to be defined as the "maintenance of capital' or keeping capital intact" and quotes Hicks's (1946) "the amount one can consume during a period and still be as well off at the end of the period" as a good definition. Goodland (1995) defines environmental sustainability as the "maintenance of natural capital" and discusses social sustainability in the context of "moral capital." The Western Sustainable Agriculture Research and Education (2019) website defines sustainable agriculture as "economically viable," "socially supportive," and "ecologically sound." If producers consider agricultural sustainability as motivational in producing GFB, then the three tenets are helpful in classifying their reasons for producing GFB and their goals for the farm. Gillespie and Mishra (2011) classify three farmer motivations for entering farming as lifestyle goals.

To elicit reasons for selecting the GFB enterprise, respondents were asked, "To what extent do you agree or disagree that your selection of a grass-fed beef enterprise as opposed to other potential farm enterprises is because of the following reasons? Please rate each reason on the scale provided below." Respondents were then asked to indicate their level of agreement for each of nine potential reasons for selecting the GFB enterprise. We selected these reasons because they were reasons that were stated in 10 interviews with GFB producers that we conducted prior to this survey. Some of the questions were also similar to those asked by Gillespie et al. (2016a) with respect to reasons for producing meat goats. Assignment of most of these reasons into one or more of the four classifications is relatively straightforward, with the possible exception of the reason, "I want to produce healthy beef." This reason is assigned under the social sustainability classification in accordance with the producer's desire to positively affect social well-being, in this case through healthy diets. Potential responses for all reasons included "strongly agree," "somewhat agree," "neutral," "somewhat disagree," and "strongly disagree." 


\subsection{Using the fuzzy pairwise comparison method to elicit producer goal structure}

To assess producer goal structure, respondents were asked, "Grass-fed beef producers may have a number of goals with respect to their operations. Below are some potential goals that you may have for your farm operation. Some goals are likely to be more important to you than others. In this section, you will be asked to compare each of eight goals with each of the other goals. We are interested in how important each goal is to you when compared to the other goals." We then elicited goal structures, with the goals falling into one or more of the same four classifications discussed earlier in regard to the reasons for entering GFB production. The goals and their assigned classifications (in parentheses) were as follows: produce healthy beef (social), maintain and conserve land (social, environmental, economic), have family involved in agriculture (lifestyle), have time for other activities (lifestyle), avoid years of loss/low profit (economic), increase net worth (economic), maximize profit (economic), and increase farm size (economic). These goals were selected because (1) they covered the major goals our presurvey interviews with GFB producers suggested would be of interest and (2) they were consistent with the goals analyzed in previous agricultural goal studies (Basarir and Gillespie, 2006; Nyaupane, Gillespie, and McMillin, 2017; van Kooten, Schoney, and Hayward, 1986). This allows us to compare goals of producers of an alternative livestock enterprise that can be argued to fit into the sustainable agriculture category of agricultural enterprises with producers of other agricultural enterprises.

A number of approaches have been utilized to elicit the goal hierarchies of agricultural producers. Major methods that have been used include basic pairwise comparisons, magnitude estimation, the analytic hierarchy process, and the fuzzy pairwise comparison (Boender, De Graan, and Lootsman, 1989; Datta et al., 1992; Ells, Bulte, and van Kooten, 1997; Harper and Eastman, 1980; Kim, Lee, and Lee, 1999; Mendoza and Sprouse, 1989; Patrick, Blake, and Whitaker, 1983; van Kooten, Schoney, and Hayward, 1986). The basic pairwise comparison requires a respondent to make a mutually exclusive decision as to which of two goals is more important. However, relative weights indicating importance of the two goals are not determined, and the two goals cannot be rated as being equally important. This "all-or-nothing" decision is a limitation associated with this method (van Kooten, Schoney, and Hayward, 1986).

With magnitude estimation, an arbitrary weight is assigned to a standard goal. The respondent is then required to weight all other potential goals relative to that standard goal (Patrick, Blake, and Whitaker, 1983). The analytic hierarchy process uses a modified pairwise comparison approach to determine the relative importance between goals. Pairs of goals are provided to respondents on a calibrated Likert-type scale with each goal positioned at opposite edges of the scale. Likert-type responses may indicate one goal to be slightly more or less important than the other, moderately more or less important, equally important, and so forth.

We use a fuzzy pairwise comparison approach as used by van Kooten, Schoney, and Hayward (1986), which is similar to the analytical hierarchical process in general design but differs in the scaling or ranking of goals compared. This method does not require respondents to select a specific discrete option assigned to a level of importance such as "absolutely important" but allows them to mark a point on an uncalibrated distance between the two goals, representing their preference.

$$
\text { Maximize profit __ }
$$

Point "I" represents the point of indifference where both goals are equally important. The closer a mark is to a goal, the more important that goal is relative to the other goal.

Using the fuzzy pairwise comparison method in our questionnaire, respondents were shown how to indicate the levels of importance of each of the goals relative to the others using three examples. The questionnaire read, "Example: Assume you are asked to compare two goals, maximize profit and produce healthy beef. If the goal maximize profit is much more important than the 
goal produce healthy beef, then you would place an ' $\mathrm{X}$ ' very near the goal maximize profit, as shown below:

Maximize profit $-\mathbf{X} \longrightarrow$ I__ Produce healthy beef.”

Respondents were then shown an example where "produce healthy beef" was slightly more important than "maximize profit" and another where they were equally important. With a total of $M$ goals, the total number of pairwise comparisons, $K$, is $K=M \times(M-1) / 2$ (van Kooten, Schoney, and Hayward, 1986). Thus, with eight goals, respondents were asked to make a total of 28 comparisons so that a comparison was made between each of the goals.

Let goal "maximize profit" be represented by letter " $A$ " and goal "produce healthy beef" by letter "B." The level of importance the respondent places on $\mathrm{A}$ over $\mathrm{B}, r_{\mathrm{AB}}$, is measured by the distance from the mark " $X$ " to $B$. Setting the total distance between A and B equal to 1, if $r_{\mathrm{AB}}<(>) 0.5$, then $\mathrm{B}$ is more (less) important to the respondent than $\mathrm{A}$; if $r_{\mathrm{AB}}=0.5$, then $\mathrm{A}$ is of equal importance to the respondent as B. Each paired comparison $r_{i j}$ for $(i \neq j)$ is obtained, where $r_{i j}=1-r_{i j}$. An individual's fuzzy preference matrix can thus be constructed as follows (van Kooten, Schoney, and Hayward, 1986):

$$
R=\left[\begin{array}{ccccccc}
0 & r_{12} & r_{13} & \cdot & . & . & r_{1 j} \\
r_{21} & 0 & \cdot & \cdot & \cdot & . & r_{2 j} \\
r_{31} & \cdot & 0 & \cdot & \cdot & \cdot & r_{3 j} \\
\cdot & \cdot & \cdot & 0 & \cdot & \cdot & \cdot \\
\cdot & \cdot & \cdot & \cdot & 0 & \cdot & \cdot \\
\cdot & \cdot & \cdot & \cdot & \cdot & 0 & r_{(i-1) j} \\
r_{i 1} & r_{i 2} & \cdot & \cdot & \cdot & r_{i(j-1)} & 0
\end{array}\right]
$$

where each element of the matrix represents the magnitude of the preference for goal $i$ relative to goal $j$. The intensity of goal $j, I_{j}$, ranges between 0 and 1 and can be calculated as

$$
I_{j}=1-\left[\sum_{i=1}^{n} r_{i j}^{2} /(n-1)\right]^{1 / 2} .
$$

The higher the value of $I_{j}$, the higher the intensity of preference for the particular goal.

\subsection{Models to analyze the impacts of farm descriptors and producer demographics on reasons for producing grass-fed beef and goal structure}

Ordered probit models are used to determine the impact of farm type and producer demographics on the importance of the nine potential reasons for entering GFB production. The ordered probit model is useful for analyzing the impacts of factors on outcomes that are inherently ordered, rather than cardinal in nature. In the case of the reasons for entering GFB production, Likert-scale questions were used to gauge the producer's agreement with each of the reasons, so the responses are ordinal in nature. The ordered probit model, as shown in Greene (2000), is presented as follows:

$$
\begin{aligned}
& \operatorname{Prob}(y=0)=\Phi\left(-\beta^{\prime} x\right), \\
& \operatorname{Prob}(y=1)=\Phi\left(\mu_{1}-\beta^{\prime} x\right)-\Phi\left(-\beta^{\prime} x\right), \\
& \operatorname{Prob}(y=2)=\Phi\left(\mu_{2}-\beta^{\prime} x\right)-\Phi\left(\mu_{1}-\beta^{\prime} x\right), \ldots, \\
& \operatorname{Prob}(y=J)=1-\Phi\left(\mu_{J-1}-\beta^{\prime} x\right),
\end{aligned}
$$

with $0<\mu_{1}<\mu_{2}<\ldots<\mu_{J-1}$ and $J$ potential outcomes. The $\mu$ 's are parameters to be estimated with $\beta$, and $\Phi($.$) refers to the cumulative normal distribution.$ 
Table 1. Independent variable definitions, means, and standard deviations, 384 observations

\begin{tabular}{|c|c|c|c|c|}
\hline Variables & Variable Definition & Mean & $\begin{array}{l}\text { Standard } \\
\text { Deviation }\end{array}$ & Median \\
\hline Total Acres & Farm size in acres & $1,537.68$ & $9,154.73$ & 233 \\
\hline $\begin{array}{l}\text { Animals } \\
\text { Raised }\end{array}$ & Number of animals raised for slaughter in 2013 & 40.01 & 127.13 & 16 \\
\hline Organic & $\begin{array}{l}\text { Whether the farm is certified organic or transitioning to certified } \\
\text { organic; } 1 \text { if yes, } 0 \text { if no }\end{array}$ & 0.14 & 0.35 & 0 \\
\hline Female & Gender of the operator; 1 if female, 0 if male & 0.24 & 0.43 & 0 \\
\hline Age & Age of the operator & 54.66 & 13.77 & 53 \\
\hline College & Whether the operator holds a 4-year college degree; 1 if yes, 0 if no & 0.70 & 0.49 & 1 \\
\hline Cow-Calf & Whether farm is involved in the cow-calf segment; 1 if yes, 0 if no & 0.80 & 0.40 & 1 \\
\hline $\begin{array}{l}\text { \% Farm } \\
\text { Income GFB }\end{array}$ & $\begin{array}{l}\text { Percent of farm income from GFB enterprise; } 1=0-20 \% \text {, } \\
2=21 \%-40 \%, 3=41 \%-60 \%, 4=61 \%-80 \%, 5=81 \%-100 \%\end{array}$ & 2.86 & 1.63 & 3 \\
\hline $\begin{array}{l}\text { Off-Farm } \\
\text { Job }\end{array}$ & Whether the operator holds an off-farm job; 1 if yes, 0 if no & 0.69 & 0.46 & 0 \\
\hline Northeast & $\begin{array}{l}\text { Farm located in CT, DE, ME, MD, MA, NH, NJ, NY, PA, RI, or VT; } \\
1 \text { if yes, } 0 \text { if no }\end{array}$ & 0.21 & 0.41 & 0 \\
\hline Southeast & $\begin{array}{l}\text { Farm located in AL, AR, FL, GA, KY, LA, MS, NC, TN, SC, VA, or WV; } \\
1 \text { if yes, } 0 \text { if no }\end{array}$ & 0.17 & 0.38 & 0 \\
\hline Southwest & Farm located in AZ, CA, NV, NM, OK, TX, or UT; 1 if yes, 0 if no & 0.15 & 0.35 & 0 \\
\hline Northwest & Farm located in AK, CO, ID, MT, OR, WA, or WY; 1 if yes, 0 if no & 0.17 & 0.38 & 0 \\
\hline Midwest & $\begin{array}{l}\text { Farm located in IL, IN, IA, KS, MI, MN, MO, NE, ND, OH, SD, or WI; } \\
1 \text { if yes, } 0 \text { if no }\end{array}$ & 0.30 & 0.46 & 0 \\
\hline
\end{tabular}

To determine the impact of farm characteristics and producer demographics on producer goal structure, we examine the $I_{j}$ 's, or the GFB producers' elicited relative levels of importance for each of the eight goals. The impacts of the factors on the $I_{j}$ 's are estimated using single-equation OLS models. The use of single-equation OLS models was motivated by the fact that all eight equations have the same regressors. When all equations have the same set of explanatory variables, the efficient estimator is single-equation OLS (Cadavez and Henningsen, 2012; Greene, 2000). (This also holds true for ordered probit equations.) Seemingly unrelated regression models would have produced more efficient estimates if the eight goal equations contained different sets of explanatory variables (Cadavez and Henningsen, 2012; Greene, 2000).

\subsection{Independent variables used in the models for producer reasons for selecting the grass-fed beef enterprise and producer goal hierarchy}

Table 1 provides descriptive statistics for farm and producer characteristics that are potential drivers of producer reasons for selecting the GFB enterprise and goal hierarchy. Two variables provide information on dimensions of farm size. Total Acres is the total number of farm acres, including land devoted to both GFB production and other enterprises, and thus is a size measure of the whole farm. Animals Raised is the total number of cattle raised to slaughter weight on the farm, providing an indicator of the scale of the GFB enterprise. The average GFB farm in our sample raised 127 animals for slaughter in 2013. Van Kooten, Schoney, and Hayward (1986), Basarir and Gillespie (2006), and Nyaupane, Gillespie, and McMillin (2017) found relationships 
between farm size and producer goal hierarchy. One variable is included to indicate the production system used for GFB production, Organic, which indicates whether the GFB operation was certified organic or transitioning to certified organic production. Fourteen percent of the farms were either certified organic or transitioning to become certified organic.

Several producer demographic variables are included. Female indicates the primary farm operator was female; $24 \%$ were female. Gillespie et al. (2016a) found producer gender to be associated with reasons for choosing a meat goat enterprise. Age is the operator's age; the average was 55 years. Research has shown differences in goal structure by operator age (Basarir and Gillespie, 2006; Nyaupane, Gillespie, and McMillin, 2017; Peterson et al., 2012), and age was associated with reasons for selecting a meat goat enterprise (Gillespie et al. 2016a). College is a discrete variable indicating whether the operator held a 4-year college degree; $70 \%$ held college degrees. Nyaupane, Gillespie, and McMillin (2017) found that meat goat operator education level affected goal structure, and Gillespie et al. (2016a) found that holding a college degree was associated with reasons why meat goat producers had selected the meat goat enterprise.

Variables are included to indicate different dimensions of a producer's involvement in activities other than the GFB enterprise. Such activities may either divert attention from or be complementary with the GFB enterprise. Cow-Calf is a dummy variable indicating whether the respondent produced weaned calves. Those involved in the cow-calf segment ( $80 \%$ of the sample) have the option of moving their weaned calves into the GFB operation. Those not involved in the cow-calf segment would likely purchase animals for grass finishing. \% Farm Income GFB indicates the percentage of the farm income originating from the GFB enterprise, providing an indicator of the financial contribution of the GFB enterprise to the whole farm. We estimate that approximately $37 \%$ of the farm income of the average GFB farm originated from the GFB enterprise. Off-Farm Job is a dummy variable indicating whether the respondent held an off-farm job; $69 \%$ held offfarm jobs. An off-farm job can divert attention from the farm but may serve as a source of income to invest on the farm. Previous studies have examined the impact of farm diversification on goal structure. Basarir and Gillespie (2006) found that producers operating more diversified operations placed lower weight on the goal "have time for other activities." Nyaupane, Gillespie, and McMillin (2017) found that, for meat goat producers, those receiving higher portions of income from the goat enterprise placed greater emphasis on "maximize profit," and those with off-farm jobs placed greater emphasis on "have time for other activities."

Regional variables include Midwest, Northeast, Southeast, Northwest, and Southwest, which are discrete variables indicating the farm was located in one of these regions. Specific regional definitions are found in Table 1. Regional differences have been found in previous producer goal structure studies (Nyaupane, Gillespie, and McMillin, 2017; Peterson et al., 2012) and "reasons for farming" studies (Gillespie et al. 2016a).

\section{Results and discussion}

\subsection{Reasons for selecting the grass-fed beef enterprise}

Table 2 provides results of the Likert-scale questions for reasons for selecting the GFB enterprise. Of the nine reasons for which levels of agreement were elicited, "I want to produce healthy beef" had with the highest level of agreement, with $86 \%$ strongly agreeing and 97\% agreeing (percent somewhat agree + percent strongly agree) that this was a reason they had elected to produce GFB. We classify this reason as a social sustainability reason, suggesting social sustainability as a strong motivator for GFB producers. Most GFB producers (about 96\%) sell GFB as meat (Gillespie et al. 2016b), as opposed to most cattle producers, who sell live animals, perhaps boosting the strength of the desire to produce healthy beef.

The reasons with the second-, third-, and fourth-highest scores were roughly equal in importance (and did not differ statistically): "producing GFB is good for the environment," "producing 
Table 2. Results of analysis of reasons for selecting the grass-fed beef (GBF) enterprise

\begin{tabular}{|c|c|c|c|c|c|c|c|}
\hline Reasons & Class & Mean & $\begin{array}{l}\text { Percent } \\
\text { Strongly } \\
\text { Disagree }\end{array}$ & $\begin{array}{l}\text { Percent } \\
\text { Somewhat } \\
\text { Disagree }\end{array}$ & $\begin{array}{l}\text { Percent } \\
\text { Neutral }\end{array}$ & $\begin{array}{l}\text { Percent } \\
\text { Somewhat } \\
\text { Agree }\end{array}$ & $\begin{array}{l}\text { Percent } \\
\text { Strongly } \\
\text { Agree }\end{array}$ \\
\hline $\begin{array}{l}\text { a. I want to produce } \\
\text { healthy beef. }\end{array}$ & Social & $4.79^{\text {bcdefghi }}$ & 1 & 0 & 2 & 11 & 86 \\
\hline $\begin{array}{l}\text { b. Producing GFB It is } \\
\text { good for the environment. }\end{array}$ & Environmental & $4.66^{\text {aefghi }}$ & 1 & 1 & 7 & 11 & 80 \\
\hline $\begin{array}{l}\text { c. Producing GFB is } \\
\text { enjoyable. }\end{array}$ & Lifestyle & $4.62^{\text {aefghi }}$ & 1 & 0 & 7 & 19 & 72 \\
\hline $\begin{array}{l}\text { d. GFB systems are more } \\
\text { sustainable than those of } \\
\text { grain-fed beef. }\end{array}$ & $\begin{array}{l}\text { Social, } \\
\text { environmental, } \\
\text { economic }\end{array}$ & $4.60^{\text {aefghi }}$ & 1 & 2 & 7 & 13 & 77 \\
\hline $\begin{array}{l}\text { e. There is strong demand } \\
\text { for GFB in my area. }\end{array}$ & Economic & 4.39abcdfghi & 1 & 4 & 9 & 29 & 58 \\
\hline $\begin{array}{l}\text { f. Raising GFB is good for } \\
\text { my family. }\end{array}$ & Lifestyle, social & $4.28^{\text {abcdeghi }}$ & 1 & 2 & 19 & 24 & 53 \\
\hline $\begin{array}{l}\text { g. GFB production is more } \\
\text { profitable. }\end{array}$ & Economic & $4.14^{\mathrm{abcdefi}}$ & 1 & 4 & 13 & 41 & 41 \\
\hline $\begin{array}{l}\text { h. I have ample land } \\
\text { suitable for grazing. }\end{array}$ & Economic & $4.06^{\mathrm{abcdefi}}$ & 3 & 8 & 10 & 34 & 45 \\
\hline $\begin{array}{l}\text { i. Producing GFB is low } \\
\text { cost. }\end{array}$ & Economic & $3.64^{\text {abcdefgh }}$ & 5 & 14 & 17 & 38 & 26 \\
\hline
\end{tabular}

Notes: Likert scale used: $5=$ strongly agree, $4=$ somewhat agree, $3=$ neutral, $2=$ somewhat disagree, $1=$ strongly disagree. Superscripts for mean scores indicate statistical differences using paired $t$-tests. Superscripts refer to the letters preceding the goals in the first column and indicate that the mean score differs from the mean score of the goal associated with the letter designation at the Prob $<0.05$ level.

GFB is enjoyable," and "GFB systems are more sustainable than those of grain-fed beef," with $90 \%$ to $91 \%$ of respondents agreeing with each, and mean scores ranging from 4.60 to 4.66 for each. We classify "producing GFB is good for the environment" as an environmental sustainability reason, "producing GFB is enjoyable" as a lifestyle reason, and "GFB systems are more sustainable than those of grain-fed beef" as a social, environmental, and economic sustainability reason. Environmental, social, and lifestyle reasons appear to be particularly important in the top four reasons for producers to have selected the GFB enterprise. Steinberg and Comerford (2009) similarly found environmental, human health, and lifestyle motivations to be reasons for producing GFB. For the present study, the other lifestyle reason for entering GFB production is "raising GFB is good for my family," ranked sixth among the nine reasons.

Excepting the reason "GFB systems are more sustainable than those of grain-fed beef," which is an overall sustainability reason encompassing the three pillars of sustainability (social, environmental, and economic), the economic reasons rank as the least important reasons for producers to have entered GFB production, with "GFB production is profitable," "I have ample land suitable for grazing," and "producing GFB is low-cost" ranking in the bottom three reasons for producers to have selected the GFB enterprise. Readers are cautioned, however, to not interpret these reasons as unimportant - the modal response for all but the low-cost reason was "strongly agree"-and one must further consider each of the statements. For instance, a lower level of agreement that GFB profitability was a reason for entering GFB production does not necessarily suggest profitability was not strongly considered-GFB could be considered equally profitable relative to other farm enterprises. Furthermore, GFB production would not likely be considered low cost compared with grain-fed beef production by most producers. 
Table 3. Results of ordered probit models: reasons for selecting grass-fed beef production

\begin{tabular}{|c|c|c|c|c|c|}
\hline Variable & $\begin{array}{l}\text { GFB } \\
\text { Production } \\
\text { Is Profitable }\end{array}$ & $\begin{array}{l}\text { Producing } \\
\text { GFB Is Low } \\
\text { Cost }\end{array}$ & $\begin{array}{l}\text { I Want to } \\
\text { Produce } \\
\text { Healthy Beef }\end{array}$ & $\begin{array}{c}\text { Raising GFB Is a } \\
\text { Good Activity for } \\
\text { My Family }\end{array}$ & $\begin{array}{l}\text { GFB Systems Are } \\
\text { More Sustainable than } \\
\text { Grain-Fed Beef Systems }\end{array}$ \\
\hline Total Acres & $\begin{array}{l}-0.0112 \\
(0.0093)\end{array}$ & $\begin{array}{l}-0.0622 \\
(0.0825)\end{array}$ & $\begin{array}{l}-0.0102 \\
(0.0079)\end{array}$ & $\begin{array}{c}0.0033 \\
(0.0083)\end{array}$ & $\begin{array}{l}-0.0061 \\
(0.0079)\end{array}$ \\
\hline Animals Raised & $\begin{array}{c}0.0013 \\
(0.0010)\end{array}$ & $\begin{array}{c}-0.0018^{\star *} \\
(0.0009)\end{array}$ & $\begin{array}{l}-0.0005 \\
(0.0005)\end{array}$ & $\begin{array}{l}-0.0001 \\
(0.0005)\end{array}$ & $\begin{array}{r}-0.0004 \\
(0.0005)\end{array}$ \\
\hline Organic & $\begin{array}{l}0.4140^{\star *} \\
(0.1874)\end{array}$ & $\begin{array}{c}0.5610^{\star * \star} \\
(0.1777)\end{array}$ & $\begin{array}{l}1.1583^{\star \star} \\
(0.4811)\end{array}$ & $\begin{array}{l}0.3356^{\star} \\
(0.1948)\end{array}$ & $\begin{array}{c}0.7707^{\star \star *} \\
(0.2946)\end{array}$ \\
\hline Female & $\begin{array}{c}-0.2859^{\star \star} \\
(0.1387)\end{array}$ & $\begin{array}{c}0.0087 \\
(0.1340)\end{array}$ & $\begin{array}{c}0.2655 \\
(0.2094)\end{array}$ & $\begin{array}{l}0.2716^{\star} \\
(0.1477)\end{array}$ & $\begin{array}{c}-0.1104 \\
(0.1639)\end{array}$ \\
\hline Age & $\begin{array}{l}-0.0832 \\
(0.0698)\end{array}$ & $\begin{array}{l}-0.0342 \\
(0.0661)\end{array}$ & $\begin{array}{c}0.1051 \\
(0.0971)\end{array}$ & $\begin{array}{c}-0.1692^{\star *} \\
(0.0724)\end{array}$ & $\begin{array}{l}-0.0836 \\
(0.0845)\end{array}$ \\
\hline College & $\begin{array}{c}0.0466 \\
(0.1323)\end{array}$ & $\begin{array}{c}-0.1375 \\
(0.1264)\end{array}$ & $\begin{array}{c}-0.4919^{\star \star} \\
(0.2095)\end{array}$ & $\begin{array}{l}-0.1497 \\
(0.1378)\end{array}$ & $\begin{array}{c}-0.1866 \\
(0.1640)\end{array}$ \\
\hline Cow-Calf & $\begin{array}{c}-0.2891^{*} \\
(0.1525)\end{array}$ & $\begin{array}{l}-0.2319 \\
(0.1430)\end{array}$ & $\begin{array}{l}-0.1738 \\
(0.2259)\end{array}$ & $\begin{array}{l}-0.1502 \\
(0.1564)\end{array}$ & $\begin{array}{l}-0.1506 \\
(0.1872)\end{array}$ \\
\hline$\%$ Farm Income GFB & $\begin{array}{c}0.1009^{\star * \star} \\
(0.0374)\end{array}$ & $\begin{array}{c}0.0185 \\
(0.0353)\end{array}$ & $\begin{array}{c}0.0616 \\
(0.0543)\end{array}$ & $\begin{array}{c}0.0130 \\
(0.0381)\end{array}$ & $\begin{array}{c}0.0203 \\
(0.0444)\end{array}$ \\
\hline Off-Farm Job & $\begin{array}{c}0.1075 \\
(0.1257)\end{array}$ & $\begin{array}{c}-0.1272 \\
(0.1201)\end{array}$ & $\begin{array}{c}0.1141 \\
(0.1791)\end{array}$ & $\begin{array}{r}-0.0105 \\
(0.1292)\end{array}$ & $\begin{array}{r}-0.0562 \\
(0.1503)\end{array}$ \\
\hline Northeast & $\begin{array}{c}-0.3130^{\star} \\
(0.1691)\end{array}$ & $\begin{array}{l}-0.1349 \\
(0.1629)\end{array}$ & $\begin{array}{c}-0.1948 \\
(0.2707)\end{array}$ & $\begin{array}{c}-0.4588^{\star \star \star} \\
(0.1756)\end{array}$ & $\begin{array}{r}-0.0768 \\
(0.2163)\end{array}$ \\
\hline Southeast & $\begin{array}{c}0.0244 \\
(0.1835)\end{array}$ & $\begin{array}{c}0.1094 \\
(0.1883)\end{array}$ & $\begin{array}{l}-0.3623 \\
(0.2592)\end{array}$ & $\begin{array}{l}-0.2558 \\
(0.1867)\end{array}$ & $\begin{array}{l}-0.1550 \\
(0.2202)\end{array}$ \\
\hline Southwest & $\begin{array}{c}0.0220 \\
(0.1989)\end{array}$ & $\begin{array}{c}0.0101 \\
(0.1883)\end{array}$ & $\begin{array}{l}-0.2771 \\
(0.2892)\end{array}$ & $\begin{array}{l}-0.2176 \\
(0.2054)\end{array}$ & $\begin{array}{l}-0.1710 \\
(0.2376)\end{array}$ \\
\hline Northwest & $\begin{array}{c}-0.0978 \\
(0.1810)\end{array}$ & $\begin{array}{l}-0.1506 \\
(0.1710)\end{array}$ & $\begin{array}{c}-0.5666^{\star \star} \\
(0.2575)\end{array}$ & $\begin{array}{c}-0.2301 \\
(0.1886)\end{array}$ & $\begin{array}{c}-0.4967^{\star \star} \\
(0.2110)\end{array}$ \\
\hline Pseudo- $R^{2}$ & 0.0407 & 0.0301 & 0.0841 & 0.0279 & 0.0393 \\
\hline Prob $>\chi^{2}$ & 0.0013 & 0.0029 & 0.0065 & 0.0540 & 0.0582 \\
\hline
\end{tabular}

Notes: Standard errors are in parentheses. Number of observations $=360 .{ }^{\star} P<0.10,{ }^{\star \star} P<0.05,{ }^{\star \star \star} P<0.01$.

Table 3 shows results of the ordered probit models for the reasons for producing GFB. For both ordered probit and OLS goal structure analyses, variance inflation factors (VIFs) were first estimated to check for multicollinearity. All VIF values obtained were $<10$. As a rule of thumb, this is an indication of no serious multicollinearity among the independent variables (Kennedy, 1992). White's and Breusch-Pagan/Godfrey's tests were used to check for heteroscedasticity (Kennedy, 1992), which was not found to be problematic for this study. Only results for models where the model chi-square is significant at Prob $<0.10$ are presented. All regression analyses can be interpreted as ceteris paribus, holding all else equal. In cases where less than $3 \%$ of the respondents indicated a specific level of agreement, for purposes of the ordered probit analysis, responses for that level were combined with the adjoining agreement levels. For example, as seen in the "producing GFB is enjoyable" distribution in Table 2, the percent strongly disagree, percent somewhat disagree, and percent neutral categories had $1 \%, 0 \%$, and $7 \%$ of the shares of responses, respectively, and were combined into one category for the ordered probit model. 
Producers of larger numbers of animals raised for GFB were less likely to have selected the GFB enterprise because of GFB being low cost. Producers may have considered total costs (higher for larger farms) rather than average costs per animal produced (generally higher for smaller-scale GFB farms) according to Qushim et al. (2018). Certified organic GFB producers were more likely than those who operated farms that were not certified organic to agree with all of the analyzed reasons for having selected the GFB enterprise. Certified organic GFB production is more stringent than GFB production that is not certified organic, with fewer input-use options. It is unclear why certified organic GFB producers would have more strongly agreed with some of the reasons for having selected GFB enterprise. Certified organic producers may be truly stronger in their agreement with each of the statements (i.e., more driven to produce a healthy beef product, farm in a more highly sustainable manner, etc.). This explanation is not, however, entirely satisfactory. We would not expect, for example, certified organic GFB producers to be more likely than "conventional" GFB producers to express that they had selected the GFB enterprise because it was low cost, as we would not expect certified organic GFB production to be lower cost than "conventional" GFB production for most producers. Another possibility is that our subsample of certified organic producers was simply more likely to respond with greater agreement to Likert-type questions on this subject.

Producer demographics influenced producer responses to the reasons for entering GFB farming questions. Females were less likely to agree that their reason for selecting the GFB enterprise was because of GFB production being profitable, and more likely to agree that they had selected it because GFB production was a good activity for their families. These economic and lifestyle results are consistent with Gillespie et al. (2016a), who found that females were less likely to have entered meat goat production because of the low cost associated with purchasing and raising goats, and that females were more likely to have agreed that they entered into meat goat production because their families could be involved in the enterprise. Older producers were less likely to agree that they had selected the GFB enterprise because GFB production was a good activity for their families. This result is consistent with Gillespie et al. (2016a), who found older producers were less likely to have agreed that they entered into meat goat production because their families could be involved in the enterprise.

Diversification into other segments of the cattle industry and/or other farm enterprises helps to explain producer responses to reasons for selecting the GFB enterprise. Producers engaged in the cow-calf segment were less likely to have agreed that they had selected the GFB enterprise because it was profitable, while those receiving higher percentages of farm income from the GFB enterprise were more likely to have agreed that they entered into GFB production because it was profitable. Overall, the farm diversification results for both cow-calf and percentage of farm income from GFB show that producers depending more heavily on the GFB enterprise were involved for economic reasons, a result that is not surprising given the greater importance of the enterprise to the farm's economic viability. Statistically significant results were also found for operator education and regions.

\subsection{Producer goal structure}

Table 4 provides summary statistics for producer goals for the farm. The goals "maintain and conserve land" and "produce healthy beef" elicited the highest scores, suggesting they were the most important, with goal scores of 0.148 . Similar to results for the reasons for selecting the GFB enterprise, social sustainability goals appear to be a strong motivating factor for GFB producers. "Have time for other activities" (lifestyle goal), "having the family involved in agriculture" (lifestyle and social goal), and "avoid years of loss/low profit (economic goal) followed with mean values of $0.139,0.136$, and 0.133 , respectively. "Increase net worth" and "maximize profit," both economic goals, followed. The lowest ranked goal, "increase farm size," was an economic goal. 
Table 4. Summary statistics of important goals of U.S. grass-fed beef producers

\begin{tabular}{|c|c|c|c|c|}
\hline Goal & Class & $\begin{array}{c}\text { Mean Goal Score } l_{j} \text {, } \\
\text { (LHS Values in } \\
\text { OLS Equations) }\end{array}$ & $\begin{array}{l}\text { Goal Share, \% } \\
\text { Importance } \\
\text { (Sums to 100) }\end{array}$ & $\begin{array}{l}\text { Standard } \\
\text { Deviation }\end{array}$ \\
\hline a. Maintain and conserve land & $\begin{array}{l}\text { Economic, social, } \\
\text { environmental }\end{array}$ & $0.518^{\text {cdefgh }}$ & 0.148 & 0.032 \\
\hline b. Produce healthy beef & Social & $0.518^{\text {cdefgh }}$ & 0.148 & 0.031 \\
\hline c. Have time for other activities & Lifestyle & $0.485^{\mathrm{abfgh}}$ & 0.139 & 0.031 \\
\hline $\begin{array}{l}\text { d. Have family involved in } \\
\text { agriculture }\end{array}$ & Lifestyle, social & $0.477^{\text {abfgh }}$ & 0.136 & 0.043 \\
\hline e. Avoid years of loss/low profit & Economic & $0.465^{\text {abfgh }}$ & 0.133 & 0.032 \\
\hline f. Increase net worth & Economic & $0.385^{\mathrm{abcdeh}}$ & 0.110 & 0.031 \\
\hline g. Maximize profit & Economic & $0.379^{\text {abcdeh }}$ & 0.108 & 0.034 \\
\hline h. Increase farm size & Economic & $0.271^{\text {abcdefg }}$ & 0.077 & 0.035 \\
\hline
\end{tabular}

Note: Superscripts for mean scores indicate statistical differences using paired $t$-tests. Superscripts refer to the letters preceding the goals in the first column and indicate that the mean score differs from the mean score of the goal associated with the letter designation at the Prob $<0.05$ level. LHS, left-hand side; OLS, ordinary least squares.

Lower weights placed on economic goals are consistent with the lower levels of agreement found for economic reasons for selecting the GFB enterprise.

Regression results showing the relationship between explanatory factors and goal structure are shown in Table 5. The "increase net worth" equation is not presented as it was nonsignificant at Prob $<0.10$ for the F-test. Larger-scale (in terms of acreage) producers weighted the goals "produce healthy beef" and "increase farm size" lower than smaller-scale producers. Larger-scale producers (in terms of animals raised) weighted "have time for other activities" lower and "maintain and preserve land" and "maximize profit" higher than smaller-scale producers. Both Nyaupane, Gillespie, and McMillin (2017) and Basarir and Gillespie (2006) found that larger-scale producers placed lower weight on the goal "have time for other activities" than smaller-scale producers, the former in reference to meat goat producers and the latter for beef and dairy producers. Nyaupane, Gillespie, and McMillin (2017) further found that larger-scale meat goat producers more heavily weighted the goal "maximize profit." The overall results for farm size suggest larger-scale GFB producers place lower emphasis on social sustainability and lifestyle goals, and greater emphasis on the economic goal of maximizing profit. Coupling the reasons for selecting the GFB enterprise results with the goal structure results, smaller-scale producers were more likely to have selected the enterprise because it was low cost and placed lower emphasis on maximizing profit and greater emphasis on having time for other activities.

Female GFB producers weighted the social sustainability goal "produce healthy beef" higher than did males, and they weighted the economic goal "increase farm size" lower than did males. Considering these results alongside reasons for entering the GFB enterprise results, females tended to place lower emphasis on economic reasons for selecting the GFB enterprise (profitability) and farm goals (increasing farm size), and greater emphasis on lifestyle reasons for selecting the enterprise (good activity for the family) and social sustainability goals for the farm.

Older producers placed higher weight on the goals "maintain and conserve land" (overall sustainability goal) and "produce healthy beef" (social sustainability goal) than younger producers, and they placed lower weight on the goal "have family involved in agriculture" (lifestyle goal) than younger producers. Consistent with these results, Basarir and Gillespie (2006) found that older beef cattle and dairy producers weighted the goal "maintain and conserve land" higher than younger beef cattle and dairy producers. Nyaupane, Gillespie, and McMillin (2017) 
Table 5. Ordinary least squares regression model results for producer goal hierarchy, U.S. grass-fed beef production

\begin{tabular}{|c|c|c|c|c|c|c|c|}
\hline & $\begin{array}{l}\text { Maximize } \\
\text { Profit }\end{array}$ & $\begin{array}{l}\text { Produce } \\
\text { Healthy } \\
\text { Beef }\end{array}$ & $\begin{array}{c}\text { Maintain } \\
\text { and Conserve } \\
\text { Land }\end{array}$ & $\begin{array}{l}\text { Increase } \\
\text { Farm } \\
\text { Size }\end{array}$ & $\begin{array}{l}\text { Avoid } \\
\text { Years of } \\
\text { Loss }\end{array}$ & $\begin{array}{l}\text { Have Time } \\
\text { for Other } \\
\text { Activities }\end{array}$ & $\begin{array}{l}\text { Have Family } \\
\text { Involved in } \\
\text { Agriculture }\end{array}$ \\
\hline Total Acres & $\begin{array}{l}0.502 \\
(0.724)\end{array}$ & $\begin{array}{l}-1.738^{\star *} \\
(0.782)\end{array}$ & $\begin{array}{l}-0.649 \\
(0.764)\end{array}$ & $\begin{array}{l}-1.023^{\star} \\
(0.604)\end{array}$ & $\begin{array}{l}0.969 \\
(0.670)\end{array}$ & $\begin{array}{l}0.160 \\
(0.761)\end{array}$ & $\begin{array}{l}1.700^{\star} \\
(0.981)\end{array}$ \\
\hline Animals Raised & $\begin{array}{l}0.005^{\star \star \star} \\
(0.001)\end{array}$ & $\begin{array}{l}-0.001 \\
(0.002)\end{array}$ & $\begin{array}{l}0.002^{\star} \\
(0.001)\end{array}$ & $\begin{array}{l}-0.25 \mathrm{E}-04 \\
(0.01)\end{array}$ & $\begin{array}{l}-1.2 \mathrm{E}-04 \\
(0.001)\end{array}$ & $\begin{array}{l}-0.005^{\star \star \star} \\
(0.001)\end{array}$ & $\begin{array}{l}-0.001 \\
(0.003)\end{array}$ \\
\hline Organic & $\begin{array}{l}-0.628 \\
(0.583)\end{array}$ & $\begin{array}{l}0.183 \\
(0.498)\end{array}$ & $\begin{array}{l}0.629 \\
(0.477)\end{array}$ & $\begin{array}{l}-0.988^{\star \star} \\
(0.493)\end{array}$ & $\begin{array}{l}0.635 \\
(0.514)\end{array}$ & $\begin{array}{l}0.106 \\
(0.480)\end{array}$ & $\begin{array}{l}0.570 \\
(0.663)\end{array}$ \\
\hline Female & $\begin{array}{l}-0.427 \\
(0.441)\end{array}$ & $\begin{array}{l}0.768^{\star} \\
(0.407)\end{array}$ & $\begin{array}{l}0.553 \\
(0.396)\end{array}$ & $\begin{array}{l}-0.828^{\star} \\
(0.460)\end{array}$ & $\begin{array}{l}0.156 \\
(0.473)\end{array}$ & $\begin{array}{l}0.208 \\
(0.417)\end{array}$ & $\begin{array}{l}-0.449 \\
(0.569)\end{array}$ \\
\hline Age & $\begin{array}{l}-0.006 \\
(0.014)\end{array}$ & $\begin{array}{l}0.037^{\star \star \star} \\
(0.011)\end{array}$ & $\begin{array}{l}0.045^{\star \star \star} \\
(0.012)\end{array}$ & $\begin{array}{l}-0.004 \\
(0.015)\end{array}$ & $\begin{array}{l}0.0190 \\
(0.013)\end{array}$ & $\begin{array}{l}-0.008 \\
(0.012)\end{array}$ & $\begin{array}{l}-0.072^{\star \star \star} \\
(0.019)\end{array}$ \\
\hline College & $\begin{array}{l}0.263 \\
(0.403)\end{array}$ & $\begin{array}{l}-0.581 \\
(0.398)\end{array}$ & $\begin{array}{l}-0.374 \\
(0.383)\end{array}$ & $\begin{array}{l}-0.256 \\
(0.428)\end{array}$ & $\begin{array}{l}-0.317 \\
(0.418)\end{array}$ & $\begin{array}{l}0.488 \\
(0.341)\end{array}$ & $\begin{array}{l}0.094 \\
(0.506)\end{array}$ \\
\hline Cow-Calf & $\begin{array}{l}-0.337 \\
(0.448)\end{array}$ & $\begin{array}{l}0.826^{\star \star} \\
(0.366)\end{array}$ & $\begin{array}{l}0.028 \\
(0.398)\end{array}$ & $\begin{array}{l}0.427 \\
(0.470)\end{array}$ & $\begin{array}{l}-0.597 \\
(0.462)\end{array}$ & $\begin{array}{l}-0.996^{\star \star *} \\
(0.380)\end{array}$ & $\begin{array}{l}0.290 \\
(0.602)\end{array}$ \\
\hline $\begin{array}{l}\% \text { Farm Income } \\
\text { GFB }\end{array}$ & $\begin{array}{l}0.004 \\
(0.117)\end{array}$ & $\begin{array}{l}0.064 \\
(0.106)\end{array}$ & $\begin{array}{l}0.244^{\star \star} \\
(0.110)\end{array}$ & $\begin{array}{l}-0.258^{\star \star} \\
(0.119)\end{array}$ & $\begin{array}{l}-0.070 \\
(0.104)\end{array}$ & $\begin{array}{l}0.037 \\
(0.105)\end{array}$ & $\begin{array}{l}-0.021 \\
(0.138)\end{array}$ \\
\hline Off-Farm Job & $\begin{array}{l}-0.211 \\
(0.389)\end{array}$ & $\begin{array}{l}0.155 \\
(0.346)\end{array}$ & $\begin{array}{l}-0.312 \\
(0.360)\end{array}$ & $\begin{array}{l}-0.016 \\
(0.408)\end{array}$ & $\begin{array}{l}0.197 \\
(0.387)\end{array}$ & $\begin{array}{l}-0.054 \\
(0.339)\end{array}$ & $\begin{array}{l}0.042 \\
(0.500)\end{array}$ \\
\hline Northeast & $\begin{array}{l}-0.306 \\
(0.436)\end{array}$ & $\begin{array}{l}-0.582 \\
(0.398)\end{array}$ & $\begin{array}{l}0.167 \\
(0.434)\end{array}$ & $\begin{array}{l}0.201 \\
(0.513)\end{array}$ & $\begin{array}{l}0.423 \\
(0.444)\end{array}$ & $\begin{array}{l}0.397 \\
(0.438)\end{array}$ & $\begin{array}{l}-0.338 \\
(0.655)\end{array}$ \\
\hline Southeast & $\begin{array}{l}1.489^{\star \star} \\
(0.695)\end{array}$ & $\begin{array}{l}-0.019 \\
(0.489)\end{array}$ & $\begin{array}{l}0.142 \\
(0.653)\end{array}$ & $\begin{array}{l}0.329 \\
(0.560)\end{array}$ & $\begin{array}{l}0.620 \\
(0.538)\end{array}$ & $\begin{array}{l}-1.421^{\star \star \star} \\
(0.489)\end{array}$ & $\begin{array}{l}-0.605 \\
(0.731)\end{array}$ \\
\hline Southwest & $\begin{array}{l}-0.530 \\
(0.795)\end{array}$ & $\begin{array}{l}1.024 \\
(0.994)\end{array}$ & $\begin{array}{l}0.571 \\
(0.725)\end{array}$ & $\begin{array}{l}1.669^{\star \star} \\
(0.758)\end{array}$ & $\begin{array}{l}-1.851^{\star \star} \\
(0.766)\end{array}$ & $\begin{array}{l}-0.182 \\
(0.844)\end{array}$ & $\begin{array}{l}-0.134 \\
(1.152)\end{array}$ \\
\hline Northwest & $\begin{array}{l}0.421 \\
(0.563)\end{array}$ & $\begin{array}{l}-0.119 \\
(0.504)\end{array}$ & $\begin{array}{l}-0.046 \\
(0.509)\end{array}$ & $\begin{array}{l}0.567 \\
(0.606)\end{array}$ & $\begin{array}{l}0.716 \\
(0.531)\end{array}$ & $\begin{array}{l}-1.032^{\star *} \\
(0.487)\end{array}$ & $\begin{array}{l}-0.194 \\
(0.636)\end{array}$ \\
\hline Constant & $\begin{array}{l}10.686^{\star \star \star} \\
(0.918)\end{array}$ & $\begin{array}{l}13.120^{\star \star \star} \\
(0.811)\end{array}$ & $\begin{array}{l}12.281^{\star \star \star} \\
(0.887)\end{array}$ & $\begin{array}{l}7.903^{\star \star \star} \\
(1.139)\end{array}$ & $\begin{array}{l}12.870^{\star \star \star} \\
(1.092)\end{array}$ & $\begin{array}{l}15.318^{\star \star \star} \\
(0.844)\end{array}$ & $\begin{array}{l}16.848^{\star \star \star} \\
(1.265)\end{array}$ \\
\hline$R^{2}$ & 0.0745 & 0.0761 & 0.0743 & 0.0483 & 0.0528 & 0.0995 & 0.0740 \\
\hline Prob $>F$ & 0.0011 & 0.0067 & 0.0009 & 0.0803 & 0.0540 & 0.0004 & 0.0101 \\
\hline
\end{tabular}

Notes: Standard errors are in parentheses; 349 observations analyzed. ${ }^{*} P<0.10,{ }^{* \star} P<0.05,{ }^{* \star *} P<0.01$.

found that older meat goat producers weighted the goal "have family involved in agriculture" lower than younger producers. Considering also the reasons for selecting the GFB enterprise results, older producers tended to place lower concern on family involvement in the GFB enterprise and the whole farm-possibly because of a lower likelihood of having offspring remaining in the household.

Cow-calf producers weighted the social sustainability goal "produce healthy beef" higher and the lifestyle goal "have time for other activities" lower than producers who were not involved in the cow-calf segment. Producers with higher percentages of their farm income from the GFB enterprise more heavily weighted the overall sustainability goal "maintain and conserve land" and placed lower weight on the economic goal "increase farm size." Considering also the results of the reasons for selecting the GFB enterprise analysis and both the cow-calf and percentage of income from GFB results, a generally greater emphasis on economic motivations for the GFB 
Table 6. Results of four fuzzy pairwise comparison goal studies, goal rankings

\begin{tabular}{|c|c|c|c|c|c|}
\hline Measure & $\begin{array}{l}\text { Current Study: } \\
\text { Sitienei, Gillespie, } \\
\text { and Scaglia }\end{array}$ & $\begin{array}{l}\text { van Kooten, } \\
\text { Schoney, and } \\
\text { Hayward }\end{array}$ & Basarir an & d Gillespie & $\begin{array}{l}\text { Nyaupane, } \\
\text { Gillespie, and } \\
\text { McMillin }\end{array}$ \\
\hline Producer population & $\begin{array}{l}\text { U.S., grass-fed } \\
\text { beef }\end{array}$ & $\begin{array}{l}\text { Saskatchewan, } \\
\text { Canada }\end{array}$ & $\begin{array}{l}\text { Louisiana, } \\
\text { U.S., } \\
\text { cow-calf }\end{array}$ & $\begin{array}{l}\text { Louisiana, } \\
\text { U.S., dairy }\end{array}$ & U.S., meat goat \\
\hline Year & 2019 & 1986 & 2006 & 2006 & 2017 \\
\hline Number of observations & 384 & 24 & 467 & 130 & 488 \\
\hline Number of goals assessed & 8 & 8 & 7 & 7 & 7 \\
\hline $\begin{array}{l}\text { Increase time off from } \\
\text { farming }\end{array}$ & & 8 & & & \\
\hline $\begin{array}{l}\text { Have time for other } \\
\text { activities }\end{array}$ & 3 & & 3.5 & 5 & 4 \\
\hline $\begin{array}{l}\text { Have family involved in } \\
\text { agriculture }\end{array}$ & 4 & & 6 & 6 & 2 \\
\hline Produce healthy beef & 2 & & & & \\
\hline Control weeds/vegetation & & & & & 6 \\
\hline $\begin{array}{l}\text { Maintain and conserve } \\
\text { land }\end{array}$ & 1 & & 1 & 4 & \\
\hline $\begin{array}{l}\text { Improve family's standard } \\
\text { of living }\end{array}$ & & 6 & & & \\
\hline $\begin{array}{l}\text { Make the most profit each } \\
\text { year (maximize profit) }\end{array}$ & 7 & 2 & 3.5 & 2 & 1 \\
\hline Increase net worth & 6 & 5 & 5 & 3 & 5 \\
\hline $\begin{array}{l}\text { Avoid years of loss /low } \\
\text { profit }\end{array}$ & 5 & 4 & 2 & 1 & 3 \\
\hline Increase farm size & 8 & 7 & 7 & 7 & 7 \\
\hline $\begin{array}{l}\text { Avoid being forced out of } \\
\text { business }\end{array}$ & & 1 & & & \\
\hline Reduce farm debt & & 3 & & & \\
\hline
\end{tabular}

enterprise and farm are seen with greater GFB specialization. Other statistically significant results were found with certified organic and regional variables.

\subsection{How do GFB producer goal structures differ from producer goals found in previous studies?}

Though we are unaware of other studies that have elicited goal structures for producers of other agricultural enterprises using an identical set of goals, several studies of other producer groups have elicited goal structures using some of the same goals in a fuzzy pairwise comparison format, thus providing us with a basis for comparison. Results are shown in Table 6. With a group of 24 Saskatchewan farmers who were involved in a farm management workshop and described as younger, more highly educated, and wealthier than most farmers, van Kooten, Schoney, and Hayward (1986) elicited goal structures over eight goals, five of which were either identical 
or very similar to ours. Their ranking differs significantly from our study, where we found "maximize profit" and "avoid years of loss/low profit" ranked relatively low and "have time for other activities ranked" ranked relatively higher, suggesting farmers in the Canadian study (van Kooten, Schoney, and Hayward, 1986) placed greater emphasis on economic goals than those in the present study.

With a sample of Louisiana cow-calf and dairy producers, Basarir and Gillespie (2006) elicited goal structures over seven goals, all of which were identical to ours, except that "produce healthy beef" was not included in theirs. Cow-calf producers were divided into four different size groups. Comparing their beef producers with our GFB producer group, similar to our study, "maintain and conserve land" was consistently in the top two of seven goals, "avoid years of loss/low profit" was consistently in the top three, and "increase farm size" was always the lowest ranked. All other goals varied significantly by farm size. Overall, our ranking is the most similar to Basarir and Gillespie's (2006) smallest cow-calf size category of 1-19 animals, with all goals in that size group in the same position or at most one ranking difference from ours. Basarir and Gillespie's (2006) dairy producer goal ranking is differs from our ranking for GFB producers, with three economic goals in the top three, followed by sustainability and lifestyle goals. Consistent with our GFB producers, "increase farm size" was their lowest-ranked goal.

The study by Nyaupane, Gillespie, and McMillin (2017) is the most recent one we are aware of that has used fuzzy pairwise comparisons to examine producer goal structure, in their case for U.S. meat goat producers. We used the same set of goals they used, except their "control weeds/ vegetation" is replaced with "maintain and conserve land," and we also included "produce healthy beef." Consistent with Basarir and Gillespie (2006) and the present study, "increase farm size" was ranked last. The major differences were that Nyaupane, Gillespie, and McMillin (2017) found "maximize profit" to be the top-ranked goal for meat goat producers, whereas it was ranked seventh of eight for the present study.

One of the major factors that makes our group of producers different from those of the previous studies discussed is that the GFB producer sample is producing under an alternative production system that can be argued to fit into the sustainable agriculture category. Thus, although economic goals are likely to be important, we see social and environmental sustainability and lifestyle goals as ranking particularly high in these producers' goals for their farms. Of the previous studies for which we compare our results, these producers have goal structures most similar to those found for the small cow-calf producers studied by Basarir and Gillespie (2006), with the addition of "produce healthy beef" coming in as the second highest of eight goals.

\section{Discussion and conclusions}

Though reasons for selecting an agricultural enterprise might differ from the eventual goals producers have for their farms, some common themes emerge regarding GFB producer motivations. The role of social sustainability reasons for selecting the GFB enterprise and goals for the farm were particularly important for GFB producers. This is reflected by results suggesting a desire to maintain and conserve land and produce healthy meat. Environmental sustainability reasons for selecting the GFB enterprise and goals for the farm were also important for GFB producers, but slightly lower ranked than social sustainability reasons and goals. Lifestyle reasons for selecting the GFB enterprise and goals for the farm were lower ranked than the social and environmental sustainability reasons and goals.

Economic reasons for selecting the GFB enterprise and goals for the farm received lower scores. Of the reasons for selecting the GFB enterprise, excepting the sixth-ranked lifestyle and social reason, economic reasons rounded out the fourth through ninth rankings. It is noted, however, that in order for a producer to continue farming, economics must be a consideration for most. It is possible that, for many GFB producers, economic considerations are a "necessary condition" for 
entering the industry and continuing farming, but the motivating drivers are of the social sustainability and environmental sustainability categories.

As expected, larger-scale producers were generally more profit oriented in their goals for the farm. Females indicated a lower level of agreement for having entered into GFB production for profitability reasons and a lower emphasis on increasing farm size as a goal for the farm. Alternatively, females tended to be more likely to agree that they entered into GFB production because it was a good activity for the family and to more heavily weight the goal "produce healthy meat." Though studies have examined production characteristics of female farmers (Hoppe and Korb, 2013), few have examined motivations of female farmers beyond enterprise-specific (Gillespie et al., 2016a) or small-sample (Ball, 2014) settings. Given that women have become more engaged as principal operators in recent years, there is opportunity to more fully examine the role of gender in reasons for entering and goals toward farming.

Previous research has provided insight as to the motivations of producers and why they farm. Consistently found in that research is that motivations differ by enterprise and farm and producer demographics. The present study contributes additional insight into that literature, particularly examining the goals and motivations of agricultural producers using alternative production systems that are often considered as more sustainable than conventional production systems. The finding that GFB producers are generally driven by social and environmental sustainability motivations, as well as lifestyle, has implications for the future of GFB production and is likely to be of interest to consumers who hold similar ideals for agricultural production.

For university personnel providing educational programs and developing research projects to serve the GFB segment of the beef industry, it will be important to understand GFB producer goals and reasons for entering production. Though programs that address economic and productivity goals will be of interest to GFB producers, those that address environmental and social sustainability issues should also hold strong interest given the importance of environmental and social sustainability goals to GFB producers.

Disclaimer. The findings and conclusions in this preliminary publication have not been formally disseminated by the U. S. Department of Agriculture and should not be construed to represent any agency determination or policy.

Financial support. This research was supported in part by the intramural research program of the U.S. Department of Agriculture, Economic Research Service. The authors also acknowledge funding from the National Institute of Food and Agriculture/Agriculture and Food Research Initiative (2011-67023-30098) and U.S. Department of Agriculture Hatch funds (LAB 4178). The survey was conducted when the authors were employed by the Louisiana State University Agricultural Center.

\section{References}

American Grassfed Association. Internet site: https://www.americangrassfed.org/ (Accessed September 25, 2018).

Ball, J.A. "She Works Hard for the Money: Women in Kansas Agriculture." Agriculture and Human Values 31, 4(2014): 593-605.

Basarir, A., and J. Gillespie. "Goals of Beef Cattle and Dairy Producers in a Multidimensional Framework." Agricultural Economics 35, 1(2006):103-14.

Bergevoet, R.H.M., C.J.M. Ondersteijn, H.W. Saatkamp, C.M.J. Van Woerkum, and R.B.M. Huirne. "Entrepreneurial Behaviour of Dutch Dairy Farmers under a Milk Quota System: Goals, Objectives and Attitudes.” Agricultural Systems 80, 1(2004):1-21.

Boender, C.G.E., J.G. De Graan, and F.A. Lootsma. "Multi-criteria Decision Analysis with Fuzzy Pairwise Comparisons." Fuzzy Sets and Systems 29, 2(1989):133-43.

Cadavez, V.A.P., and A. Henningsen. "The Use of Seemingly Unrelated Regression to Predict the Carcass Composition of Lambs." Meat Science 92, 4(2012):548-53.

Datta, V., K.V. Sambasivarao, R. Kodali, and S.G. Deshmukh. "Multi-attribute Decision Model using the Analytic Hierarchy Process for the Justification of Manufacturing Systems." International Journal of Production Economics 28, 2(1992):227-34.

Dillman, D.A., J.D. Smyth, and L.M. Christian. Internet, Phone, Mail, and Mixed-Mode Surveys: The Tailored Design Method. Hoboken, NJ: John Wiley and Sons, 2009. 
Ells, A., E. Bulte, and G.C. van Kooten. "Uncertainty and Forest Land Use Allocation in British Columbia: Vague Priorities and Imprecise Coefficients." Forest Science 43, 4(1997):509-20.

Gillespie, J., and A. Mishra. "Off-farm Employment and Reasons for Entering Farming as Determinants of Production Enterprise Selection in US Agriculture." Australian Journal of Agricultural and Resource Economics 55, 3(2011):411-28.

Gillespie, J., N. Nyaupane, B. Dunn, and K. McMillin. "Why Do Farmers Decide to Produce Meat Goats? Evidence from the United States." Agriculture and Human Values 33, 4(2016a):911-27.

Gillespie, J., I. Sitienei, B. Bhandari, and G. Scaglia. “Grass-Fed Beef: How Is It Marketed by US Producers?” International Food and Agribusiness Management Review 19, 2(2016b):171-88.

Goodland, R. "The Concept of Environmental Sustainability.” Annual Review of Ecology and Systematics 26(1995):1-24.

Greene, W.H. Econometric Analysis. 4th ed. Upper Saddle River, NJ: Prentice Hall, 2000, pp. 201-15.

Gwin, L. "Scaling-up Sustainable Livestock Production: Innovation and Challenges for Grass-Fed Beef in the U.S." Journal of Sustainable Agriculture 33, 2(2009):189-209.

Gwin, L., C.A. Durham, J.D. Miller, and A. Colonna. "Understanding Markets for Grass-Fed Beef: Taste, Price, and Purchase Preferences." Journal of Food Distribution Research 43, 2(2012):91-128.

Harper, W.M., and C. Eastman. "An Evaluation of Goal Hierarchies for Small Farm Operators." American Journal of Agricultural Economics 62, 4(1980):742-47.

Hicks, J.R. Value and Capital. 2nd ed. Oxford, UK: Clarendon Press, 1946.

Hoppe, R.A., and P. Korb. Characteristics of Women Farm Operators and Their Farms. Washington, DC: U.S. Department of Agriculture, Economic Research Service, Economic Information Bulletin No. 111, April 2013.

Kennedy, P. A Guide to Econometrics. 3rd ed. Cambridge, MA: MIT Press, 1992.

Kim, P.O., K.J. Lee, and B.W. Lee. "Selection of an Optimal Nuclear Fuel Cycle Scenario by Goal Programming and the Analytic Hierarchy Process.” Annals of Nuclear Energy 26, 5(1999):449-60.

Kliebenstein, J.B., D.A. Barrett, W.D. Heffernan, and C.L. Kirtley. "An Analysis of Farmers' Perceptions of Benefits Received from Farming." North Central Journal of Agricultural Economics 2, 2(1980):131-36.

Lozier, J., E. Rayburn, and J. Shaw. "The Decision to Finish Cattle on Pasture: An Ethnographic Approach.” Journal of Sustainable Agriculture 28, 3(2006):5-23.

Lusk, J.L., J. Roosen, and J.A. Fox. "Demand for Beef from Cattle Administered Growth Hormones or Fed Genetically Modified Corn: A Comparison of Consumers in France, Germany, the United Kingdom, and the United States." American Journal of Agricultural Economics 85, 1(2003):16-29.

Mathews, K.H., Jr., and R.J. Johnson. Alternative Beef Production Systems: Issues and Implications. Washington, DC: U.S. Department of Agriculture, Economic Research Service, LDPM-218-01, 2013.

McBride, W., and K. Mathews, Jr. The Diverse Structure and Organization of U.S. BeefCow-calf Farms. Washington, DC: U.S. Department of Agriculture, Economic Research Service, Economic Information Bulletin No. 73, March 2011.

McCluskey, J.J., T.I. Wahl, Q. Li, and P.R. Wandschneider. "U.S. Grass-Fed Beef: Marketing Health Benefits." Journal of Food Distribution Research 36, 3(2005):1-8.

Mendoza, G.A., and W. Sprouse. "Forest Planning and Decision Making under Fuzzy Environments: An Overview and Illustration.” Forest Science 35, 2(1989):481-502.

Nyaupane, N.P., J.M. Gillespie, and K.W. McMillin. "How Important Is Farm Profitability to Meat Goat Farmers?" Professional Animal Scientist 33, 5(2017):596-603.

Patrick, G.F., B.F. Blake, and S.H. Whitaker. “Farmers' Goals: Uni- or Multi-dimensional?” American Journal of Agricultural Economics 65, 2(1983):315-20.

Peterson, H.H., A. Barkley, A. Chacón-Cascante, and T.L. Kastens. "The Motivation for Organic Grain Farming in the United States: Profits, Lifestyle, or the Environment?” Journal of Agricultural and Applied Economics 44, 2(2012):137-55.

Qushim, B., J.M. Gillespie, B.D. Bhandari, and G. Scaglia. "Technical and Scale Efficiencies of US Grass-Fed Beef Production: Whole-Farm and Enterprise Analyses." Journal of Agricultural and Applied Economics 50, 3(2018):408-28.

Smith, D., and D.F. Capstick. "Establishing Priorities among Multiple Management Goals." Journal of Agricultural and Applied Economics 8, 2(1976):37-43.

Spiselman, A. “In the Aisles: Is Grass-Fed Greener?” Meatingplace (September 2006):74-77.

Steinberg, E.L., and J.W. Comerford. "Case Study: A Survey of Pasture-Finished Beef Producers in the Northeastern United States.” Professional Animal Scientist 25, 1(2009):104-8.

Umberger, W.J., D.M. Feuz, C.R. Calkins, and K. Killinger-Mann. "US Consumer Preference and Willingness-to-Pay for Domestic Corn-Fed Beef versus International Grass-Fed Beef Measured through an Experimental Auction." Agribusiness: An International Journal 18,4(2002):491-504.

U.S. Department of Agriculture, Agricultural Marketing Service. Conference Call on Withdrawal of our Grass (Forage) Fed Marketing Claim Standard and Naturally Raised Marketing Claim Standard, January 14, 2016. 2016. Internet site: https:/www.ams.usda.gov/sites/default/files/media/Grass\%20Fed\%20Conference\%20Call\%20Notes\%2001\%2014\%2016.pdf (Accessed August 12, 2019).

U.S. Department of Agriculture, Agricultural Marketing Service. “Grass Fed Marketing Claim Standard.” Internet site: https://www.ams.usda.gov/grades-standards/beef/grassfed (Accessed September 25, 2018). 
van Kooten, G.C., R.A. Schoney, and K.A. Hayward. "An Alternative Approach to the Evaluation of Goal Hierarchies among Farmers.” Western Journal of Agricultural Economics 11, 1(1986):40-49.

Western Sustainable Agriculture Research and Education. "What Is Sustainable Agriculture?” Internet site: http://www. westernsare.org/About-Us/What-is-Sustainable-Agriculture (Accessed August 12, 2019).

Xue, H., D. Mainville, W. You, and R.M. Nayga, Jr. "Consumer Preferences and Willingness to Pay for Grass-Fed Beef: Empirical Evidence from In-store Experiments.” Food Quality and Preference 21, 7(2010):857-66.

Cite this article: Sitienei I, Gillespie J, and Scaglia G (2020). U.S. Grass-Fed Beef Producers: Goal Structure and Reasons for Enterprise Selection. Journal of Agricultural and Applied Economics 52, 78-95. https://doi.org/10.1017/aae.2019.36 